\title{
Jerusalem and the riparian simile
}

\author{
Shaul E. Cohen ${ }^{\mathrm{a}, *}$, David A. Frank ${ }^{\mathrm{b}}$ \\ a Department of Geography, The University of Oregon, Eugene, OR 97303, USA \\ b Robert D. Clark Honors College, The University of Oregon, Eugene, OR 97403, USA
}

\begin{abstract}
Many see the city of Jerusalem as an intractable religious political issue, beyond the pale of negotiation and problem solving. This view reflects a set of problematic assumptions, including beliefs that Jerusalem produces a contest between maximalist claims that only power can resolve. In this article, we conduct a conceptual exercise designed to rethink Jerusalem as an issue of political geography open to needs-based bargaining. Drawing from evidence in the Transboundary Freshwater Dispute Database, we suggest that riparian negotiations offer an analogue that might be used to restructure the discourse used in the negotiations about Jerusalem. We propose the use of a riparian simile in which negotiators begin with the assumption that "the conflict over Jerusalem is like international water disputes." Riparian negotiations encourage movement from sovereign rights to functional needs, the use of time as a flexible variable, a focus on beneficial uses, and the creation of language recognizing local contingencies. (C) 2002 Published by Elsevier Science Ltd.
\end{abstract}

Keywords: Analogic thinking; Conflict; Jerusalem; Metaphor; Riparian simile; Territory

And there are days here when everything is sails and more sails, even though there's no sea in Jerusalem, not even a river. Everything is sails: the flags, the prayer shawls, the black coats, the monks' robes, the kaftans and kaffiyehs, young women's dresses and headdresses, Torah mantles and prayer rugs, feelings that swell in the wind and hopes that set them sailing in other directions.

Yehuda Amichai, Jerusalem, Jerusalem, Why Jerusalem? (2000:138)

\footnotetext{
* Corresponding author. Tel.: +1-541-346-4500; fax: +1-541-346-2067.
}

E-mail address: scohen@oregon.uoregon.edu (S.E. Cohen). 


\section{Introduction}

Geographers are at the forefront in conceptualizing issues of territory, boundaries, space, and place. Yet, there is always room for innovation, adding to our work through dialogue with scholars from other fields interested in similar topics (Elazar, 1999; Lapid, 1999; Lustick, 1999; Murphy, 1999; Newman, 1999). In a recent special issue of Political Geography (vol. 18, number 8), Newman and others suggested that geographers and colleagues from different disciplines engage in fruitful collaborations to better reveal how perceptions of culture and place interact. Indeed, Lapid, drawing from the work of Thompson-Klein (1996:224) argued that the best interdisciplinary work "requires an added form of knowledge." We find substance for this suggestion in considering the attempts to resolve the conflict over the city of Jerusalem, ${ }^{1}$ a dispute that has confounded scholars and diplomats alike for many decades. Our article represents an interdisciplinary collaboration designed to bridge the disciplines of geography and political communication, and draws upon the experience of both authors in researching the geographical strategies and symbols used by Israelis and Palestinians.

To this end, we conduct a conceptual exercise aligning the study of territory and space (geography) with the study of symbol (political communication). Geography offers insights on the issues of spatiality, territorial limits, topography, location; the discipline of political communication displays how these issues are transformed into metaphors, similes, tropes, and, in turn, play a critical role in negotiations about language and discourse of territory. As Murphy notes, "The power of language in shaping geographical arrangements and understandings is a theme of growing importance within geography (1990:545)." Murphy observes that the "challenge for those of us concerned with the role of territory in human affairs is to explore the ways in which discourse shapes the formulation and pursuit of territorial objectives (1990:545)." In the spirit of the call for interdisciplinary study of territory, we critique the language used to depict Jerusalem and offer an alternative discourse about the issues of space, territory, boundaries, and sovereignty raised by the Jerusalem issue. We see our work as part of a larger movement that seeks new language and frameworks for the problems of political geography (Newman \& Paasi, 1998). Our project should also be of interest to scholars of international relations who struggle with the problems of the Middle East (Boulding, 1994) and global issues of peace and conflict (Wapner, Ruiz, \& Falk, 2000).

Though political geographers are often drawn to disputes that are deemed intractable, even the most difficult situations may benefit from new approaches and reconsideration. An example of this is the ongoing efforts to resolve land disputes in postapartheid South Africa, where Robinson notes that:

\footnotetext{
${ }^{1}$ We are sensitive to the language used in describing the city that is the subject of this essay. We use the names "Jerusalem" and "Hebron" in the spirit of a common ground respecting the Jewish, Muslim, Christian, and other meanings associated with these places. In the same spirit, we follow the common English language tradition in using the name "Temple Mount" to include the Dome of the Rock, the Western Wall, and al-Aqsa Mosque.
} 
Negotiations in a situation of violence and political conflict where the aim is the erasure of opponents (literally and politically) neither promote nor display democracy. And yet, even in these cases, a mutual recognition and transformation of political positions in the course of political negotiation did occur, and it is not insignificant that the final settlement took place through agreed-upon legal procedures and non-violent political debate (Robinson, 1998:546).

Jerusalem appears to be a conflict at least as thorny as that of South Africa and the promise of principled negotiations should give hope to those seeking a political solution to the problem of Jerusalem. Our purpose here is to suggest principles drawn from riparian negotiations to help reframe the territorial conflict over the city.

We hope that scholars and others will see reason to use a riparian simile, "Jerusalem is like an international water conflict," in considering new methods of breaking the impasse over the city. This formulation can serve as a significant modification in thinking about territorial disputes. Jerusalem has thwarted the efforts of skilled diplomats to date, and we do not propose a "solution" or end product for the negotiations over the city. Due in part to its iconographic power, Jerusalem has confounded the most experienced negotiators, framed by many as a zero-sum conflict that cannot be resolved by means other than force. For example, the Sharm el-Sheikh FactFinding Committee (2001), also known as the Mitchell Committee, noted in its final report the deeply entrenched positions of Israelis and Palestinians, outlined a proposal for a cease-fire, but did not offer principles, a framework, or a language for a deeper reconciliation.

Riparian conflicts emanate from deeply held spiritual, religious, national, and ideological commitments to water. As Hillel (1994: 23-24) writes, "In the Judeo-Christian and Muslim traditions, as well as in many of the eastern religions, water is regarded not only as a physical cleansing agent but also a source of spiritual purification and renewal." Elmusa argues that physical and cultural factors that comprise the Israeli-Palestinian water conflict may make it "the most complex of all issues" involving disputes in the Middle East (1997:13). Like the conflict over Jerusalem, international (and domestic) disagreement over water is multidimensional (Feitelson, 2001). Unlike the diplomacy applied to Jerusalem, riparian negotiations have produced durable, needs-based agreements that generate lessons that can be applied to non-riparian conflicts and can create space in which the many existing or future proposals for disposition of the city can be more productively developed.

Riparian agreements are often the product of cooperation between the protagonists and outside actors. Indeed, in many cases the impetus for resolution is augmented by a combination of carrot and stick provided by ostensibly neutral parties, whether on a unilateral or multi-lateral basis. There is no shortage of this type of involvement in relation to the Palestinian-Israeli and broader regional conflict. Most of the negotiated agreements between Israel and its neighbors have been under the auspices of, or in conjunction with, international bodies or conferences, and almost always with the participation of the US and European countries. Today there are outside powers monitoring peace agreements (or the lack thereof) in southern Lebanon, the Golan Heights, the Sinai Peninsula, and in Hebron. Ongoing negotiations draw the partici- 
pation of a number of "partners" to the peace process and there is every reason to believe that the combination of bribery, cajolery, and threat will continue to abet the search for solutions in the region. To date, they have produced peace between Israel and Egypt and Israel and Jordan, and both tangible and intangible benefits from these treaties are obvious to the protagonists, yet the conflict between Israelis and Palestinians, with Jerusalem at the core, persists.

Providing a stimulus for our riparian simile, Wolf (1999b:256) argues that, at the international level, "there has never been a single war fought over water," but that there has been "occasional, intense political instability and that, on a small scale, acute violence can result." In a series of articles and books, he has developed an impressive research base on riparian disputes and negotiations. Indeed, Wolf's Transboundary Freshwater Dispute Database (TFDD), which provides summaries and full text of 150 water-related treaties, demonstrates that many water disputes originate in rights-based zero-sum conflict. ${ }^{2}$ Over time, these conflicts eventually yield to innovative and lasting measures that, if not always entirely resolving the disputes, generate and sustain cooperative approaches to resource sharing.

Soffer (1999:161) argues that a number of water wars have been fought between Israel and Arab states. Yet, Homer-Dixon in his recent review of the evidence suggests that "the historical and contemporary evidence shows that violent conflict related to river water is almost always internal rather than international" (HomerDixon, 1999:141). However the conflicts are classified, the consensus of evidence shows that riparian negotiations have often produced durable agreements, creating the conditions necessary for mutually beneficial and innovative solutions to water problems (Bingham, Wolf, \& Wohlgenant, 1994; Gleick, 1998; Homer-Dixon, 1999; Wescoat, 1995; Wolf, 1999a, 1999b, 2000).

One illustration of this consensus is the 1994 Israeli-Jordanian Peace treaty, which contains important and enduring agreements on water. Transboundary cooperation between Israel and Jordan in regard to their common watershed is a recent and significant development in the region, and a key element of the peace established between the two states. Illuminating the thesis that riparian negotiations spark creativity, Wolf notes:

In what will no doubt become a classic modification of the tenets of international law, Israelis and Jordanians invented legal terminology to suit particularly local requirements in their 1994 peace treaty. In negotiations leading up to the treaty, Israelis, arguing that the entire region was running out of water, insisted on discussing only water "allocations;" that is, the future needs of each riparian. Jordanians, in contrast, refused to discuss the future until past grievances had been addressed - they would not negotiate "allocations" until the historic question of water "rights" had been resolved. There is little room to bargain between the past and the future, between "rights" and "allocations." Negotiations reached an impasse until one of the mediators suggested the term "rightful allocations" to

\footnotetext{
2 The database can be found at http://terra.geo.orst.edu/users/tfdd/index.html (2001).
} 
describe simultaneously historic claims and future goals for cooperative projects - this new term is now immortalized in the water-related clauses of the Israel-Jordan Treaty of Peace (1999).

This treaty between Israel and Jordan on water rights has remained intact in the face of periods of increased tension ('Al-Ra'y', 2000). Even in the midst of the Intifada II, Israelis and Jordanians are cooperating to preserve the Dead Sea (SiegelItzkovich, 2001) and leaders in both countries recognize the need to share water (Gorbachev, 2000).

That the water treaty between Israel and Jordan has held in the face of tension suggests something can be learned from these negotiations that might be useful for the Jerusalem issue. In comparing riparian disputes with the conflict over Jerusalem, we use analogic thinking, defined as the cognitive act of comparing two unique domains for the purpose of establishing relevant similarities and differences. In the next section, we discuss the untapped power of analogical thinking. We then consider the study of metaphors by geographers, the primary critical tool used in the analysis of geographical language (Buttimer, 1982; Livingston, 1981; Porteous, 1986, 1990; Smith \& Katz, 1993, Willems-Braun, 1997), and argue that the emphasis on metaphor unduly restricts an understanding of the role played by discourse in "shaping geographical arrangements and understandings (Murphy, 1990)," and offer the simile as another resource for the analysis of political geography.

\section{Analogical thinking, metaphors, and similes in geography}

When we compare riparian disputes with the Jerusalem conflict for the purpose of establishing relevant similarities and differences, we engage in analogical thinking. "Despite its importance to all disciplines.... [analogy] remains the least well understood and explicated form of reasoning" (Brewer, 1996). As Perelman and OlbrechtsTyteca (1969), Brewer (1996), Sunstein, (1993), and Holyoak and Thagard (1995) write, analogical thinking can be the source of creativity and problem solving. Perelman and Olbrechts-Tyteca (1969:385) observe, "analogies are important in invention and argumentation fundamentally because they facilitate the development and extension of thought." Holyoak and Thagard (1995:7) write that to "propose an analogy, or to simply understand one, requires taking a kind of mental leap. Like a spark that jumps across a gap from the source analog is carried over to its target." For our purposes, the source analog is Jerusalem, a "known domain" that exhibits "familiar patterns" (Holyoak and Thagard, 1995:2), and riparian issues comprise the target analog, constituting a "relatively unfamiliar domain".

Analogical thinking is enacted when an assertion is made that two different domains share some relevant characteristics. The relevant similarities are not deduced, but are inferred from the particulars in each domain. Analogical thinking places an emphasis on the details of the domains compared. The reasoning takes place on a horizontal plane, as the domains are set side by side and are not collapsed or conflated. The thinking is "bottom up" from the details to principles rather than 
the reverse. Analogical thinking does not begin with or depend upon a preexisting set of conclusions or covering laws. Generalizations are based on the inferences of relevant similarities produced by the comparison of two domains. When we argue that the conflict over Jerusalem is like international water disputes, we argue that there are relevant similarities between the source (conflicts and negotiations over Jerusalem) and the target (conflicts and negotiations over water).

Analogies are often expressed in discourse as metaphors and similes. Metaphors are condensed analogies, and a host of geographers have employed metaphors in their analysis of space (Buttimer, 1982; Livingston \& Harrison, 1990; Porteous, 1986, 1990; Smith \& Katz, 1993, Willems-Braun, 1997). Despite its preferred use in the symbolic construction of space, metaphor can be problematic in that it may condense and sometimes collapse distinctions necessary for a more robust understanding of geographical issues. Metaphors suggest "domain X is domain Y." The metaphor can fuse $\mathrm{X}$ and $\mathrm{Y}$, producing a literalism that can resist modification (Sunstein, 1993). When the metaphor "Jerusalem is Holy" is used, the source (Jerusalem) is collapsed into the target (The Holy), transferring the city into the realm of the sacred. Indeed, one obstacle to needs-based negotiations over Jerusalem may be the barrier erected by the "Jerusalem is Holy" metaphor. Once a territory is deemed sacred by a people, as the Mufti of Jerusalem (Palestine, 2001) and Israel's Chief Rabbis have declared (Reeves, 2001), negotiations become blasphemy.

In contrast to the metaphor, similes are expanded analogies, holding that "domain $\mathrm{X}$ is like domain Y." The word "like" places a wedge between $\mathrm{X}$ and $\mathrm{Y}$, inviting a comparison rather than a fusion of the two domains. While metaphor condenses realities under the same linguistic umbrella, simile places the objects of comparison in dialectical tension. Because it juxtaposes domains, revealing spheres of commonality and difference (Bridgeman, 1996), simile can become the engine for a conceptual restructuring of a conflict, doing so by avoiding the tendency of metaphor to bury difference. When the riparian simile positions the Jerusalem conflict as the source and riparian issues as the target of the analogy, it invites a search for relevant similarities.

In the case of Jerusalem, the simile, rather than the metaphor, may enhance the power of analogical thinking, helping to reveal new insights on what might be done.

\section{The riparian exeperience and Jerusalem}

Jerusalem, seen by Arabs and Jews as a source of religious and political identity, was a key unresolved issue at the end of the 20th century, contributing to an end of the Oslo peace process and Intifada II (for extended Arab and Israeli treatments of Jerusalem, see Benvenisti, 1996; Khalidi, 1997). Alpher (2000) reports that the negotiation over Jerusalem hinged on sovereignty, and that President Clinton offered some six sovereignty options at the July 2000 Camp David summit: "sovereignty of God; suspended sovereignty; sovereignty of the UN Security Council and select Muslim nations; Palestinian sovereignty on the surface of the Mount, where the mosques are located, and Israeli 'virtual sovereignty' below ground, where the ruins of the 
actual Temple lie." Palestinian leader Yasser Arafat was unwilling to entertain discussions of Palestinian concessions of sovereignty, eliciting a similar response on the part of the Israelis (Sontag, 2001). Although sovereignty is certainly a key issue in the Jerusalem negotiations, it did not sponsor the creation of a shared language that both sides could use in describing a shared Jerusalem.

Framing Jerusalem with the lens of sovereignty encouraged a rights-based, rather than a needs-based, orientation. Led to its logical conclusion, negotiations based on raw sovereignty leads to separation, division, and unbreachable redlines. Simply put, unmediated sovereignty options do not foster a framework that privileges the needs of all the negotiators, they do not invite negotiators to consider the most efficient use of the resource, nor do they offer a language designed to secure sharing (Murphy, 1990).

Assuming that Palestinian and Israeli sovereignty must remain absolutes, President Clinton made use of the "bridge metaphor" during the Fall 2000 negotiations to foster ethnic territorial continuity in Jerusalem, and proposed the construction of six bridges linking ethnically homogeneous areas of the city. Benvenisti (2000) argued the bridge metaphor violates the reality that Jerusalem is a "living organism," ill suited for ethnic separation. Instead, he writes, "Jerusalem is more than a sum of its ethnic components" and that the model of "separation" should be replaced by the opposite model, that of "cooperation." In scoring the use of the bridge metaphor, Benventisti illustrated the need for an alternative symbolic blueprint for needs-based negotiation over Jerusalem, one that treats the city as a living organism.

Riparian negotiations offer useful analogs for the construction of blueprints needed for the possibility of Jewish and Palestinian rapprochement on the issue of Jerusalem. Riparian negotiations demonstrate that it is possible for a resource to be shared by communities that see it as essential to their identity in both spiritual and political terms. In the next section, we draw upon a riparian analogue to derive four principles that we use in construction of a simile for Jerusalem.

\section{International riparian conflict as an analogue}

Scholars of international riparian conflicts (IRCs) describe the process whereby seemingly intractable situations [Kolars (1997) likens them to the Solomonic baby] are transformed into stable, innovative, and cooperative structures for resource sharing (Wescoat, 1992; Wolf, 1999a,b). In this section we briefly review the nature of IRCs, examine the language of international treaties, and consider riparian negotiations as a useful resource needed for a reframing of the Jerusalem issue.

Similar to the disputes about Jerusalem, conflicts over water include "religious animosities, ideological disputes, arguments over borders, and economic competition" Gleick, 1998:124). Water conflict often exposes issues of significant resonance such as issues of identity, nationalism, religious belief, and tradition (Schama, 1996:15). Both literally and metaphorically, water is the source of life, and the allocation and control of water, particularly in conditions of scarcity, quickly triggers identity responses, whether they are local, tribal, religious, or national. Its transfer, 
use, and quality, therefore, can contribute to conditions that generate great passion and necessitate careful negotiations to resolve what appear to be intractable, zerosum situations, much as Jerusalem does today.

The basic dynamics of IRCs are fairly straight-forward: competing parties initially seek to utilize water in a way that is to their own advantage, often irrespective of difficulties that such use may impose on co-riparians. Claims supporting existing or future use fall into a number of common categories that tap both geography and history as legitimating factors (Murphy, 1990). The struggle over water is frequently accompanied and can be driven by the effort to control the discourse of rights and communal meaning associated with the resource itself. Water negotiations provide an interesting analogue for Jerusalem because they must deal with the technologies of water resource management and issues of religion, identity, and nationalism. Similarly, negotiations over Jerusalem must account for the city's mechanic and organic needs, and as a symbol of identity, religion, and nationalism as well.

On the face of it, the general characteristics of IRCs hold little in common with the particulars of the dispute over control of Jerusalem. As opposed to the political control of a specific space-the city-riverine conflicts entail competition over a moving, liquid, natural resource that "ignores political boundaries" (Wolf, 1999a,b:3). Water can be diminished in both quantity and quality through use, its value shifts according to both where it is in the basin and whether it is still relatively usable or already degraded. Riparian conflict is often about use of a substance that, at least prior to the conflict, traveled from the domain of one interested party to that of another and thus was used sequentially and in a linear fashion, rather than simultaneously or in a back-and-forth progression. In addition, time is a key variable in riparian conflict and its value can vary in intensity. Arguments in riparian disputes pivot on two general issues: the historic use of the water and the "rightful use" of the water. Upstream riparians often assert that, in-as-much as the water originates in their sovereign territory, they are entitled to use it as they wish. For those states, the compelling factor is sovereignty, and the water, which is within their territory, may be taken regardless of other's need, and even if use of the water will lead to significant harm to downstream users. To support their position they enlist a range of international agreements turning on issues of sovereignty, all of which support the independence of the state in controlling resources within its recognized boundaries.

Downstream riparians argue that once a use is established it takes precedence over all subsequent demands on the resource, irrespective of its location or nature, and is superior to claims of sovereignty. They argue that upstream riparians have no right to use the water if it will harm the established downstream uses. Both claims, historic use and what is called "reasonable and equitable use," lend themselves to extreme positions and the pessimistic outlook that water, in many places already a scarce resource, will be a source of war (Butts, 1997:10; Gleick, 1993:11; Homer-Dixon, 1994:12; Soffer, 1999:14; Starr, 1991:9). The threat of war and an understanding that there is no alternative to shared use, produce negotiated settlements far from beginning positions as negotiations unfold as a process of working from the polarization of extreme views to cooperative measures. Water negotiators are aware that the financial costs in reaching a settlement are less than the burdens imposed by 
military conflict and that the absence of an agreement guarantees that conflict in-asmuch as water needs simply will not disappear.

Based on his analysis of 49 treaties relating to international water resources, Wolf (1999a,b) observes:

One interesting pattern which emerges, is that while many international water negotiations begin with differing legal interpretations of rights, whether measured by hydrography or chronology, they often shift rather to a needs-based criteria for water allocations, as measured by some mutually agreeable parameter such as irrigable land or population. Mostly, one is struck by the creativity of the negotiators in addressing specific language to each very specific local setting and concerns.

We believe there are four reasons why this pattern recurs in water negotiations: first, the bargaining sessions tend to produce a psychology that cultivates recognition of the needs of others. All parties understand that water is an indispensable need. Second, the negotiations emphasize the quantification of needs rather than encouraging a rehearsal of respective rights. Negotiations of a quantitative nature are more tangible and promote progress toward an agreement. Third, the growing number of successful resolutions to water problems draws the attention of negotiators to alternative analogues from which they can draw (Wolf, 1999a,b). Fourth, the riparian negotiation sequence generates a language that acknowledges the needs of all parties. Riparian negotiators tend to move from static, zero-sum positions displayed in the left column in Table 1, to those reflecting greater flexibility and ingenuity in the right column.

Wolf has identified four interrelated assumptions in riparian negotiations useful for our purposes.

\section{A shift from rights to needs}

Riparian negotiators move from a rights-based orientation rooted in absolute sovereignty to a needs-based outlook. In some riparian bargaining sessions, needs such as irrigable land and drinking water for people drive the negotiations, rather than sovereignty. Data drawn from the TFDD demonstrates agreements that placed needs

Table 1

Progression of riparian negotiations

Conflict stance (rights) Post-negotiation stance (needs)

Permanent control of the resource

Exclusive use

Sovereign interests in policy/planning/management Bi-lateral or multi-lateral interests in

Degrading uses
Sequential use or seasonal use

Shared use policy/planning/management

Sustainable uses 
before sovereign rights: India/Pakistan (1960, Indus), Egypt/Sudan (1929, 1959, Nile), and negotiations leading to the Johnston Accord (1956, Jordan), and the IsraelPalestinian Interim Agreement (1995, shared aquifers).

The shift from a sovereign rights orientation to one that features needs is due, in part, to the recognition that the other party has a basic need for the object in dispute. This recognition results because negotiators come to understand that even one's enemy requires water. In addition, a shift from sovereign rights to needs helps to move the negotiations to tangible and measurable objectives. In riparian negotiations, the human need for drinking water and the amount of water needed to irrigate land, are quantified and set forth as need-based objectives for negotiations.

\section{A focus on time rather than on sovereignty}

Liberated from a focus on sovereign rights, riparian negotiators can take a more flexible view of space and time. If the focus is on temporal human needs rather than the preservation of sovereign rights throughout time, then use of a given resource can move from one party to another in time. In riparian treaties, time is used as a variable in the construction of agreements designed to meet needs. For example, some riparian treaties allow one party to control the water for a given month or season or flow regime, while the other party cedes some or all of its rights for that period, with compensation coming at another time. In making this transition, both parties benefit from the water, and do not place their neighbors at a competitive disadvantage.

\section{Calibration to beneficial use}

Riparian negotiators seek to maximize the efficient use and value of water. Again, because efficient use and value may be a function of time, water treaties acknowledge that one party might gain more benefits at a given time from the water than the other party. Wolf illustrates this with the Canadian-US agreement on the Niagara Falls: because the benefit of tourism is greater than the hydropower generation that might result, the two countries have agreed to allow for a greater flow over the falls during the daylight hours. Riparian treaties also reflect a focus on the different benefits that result from the same body of water. One country, for example, might best use the water for irrigation, another for power generation. As such, the treaties would calibrate for the different temporal needs of the two countries that require the same water resource.

\section{Language recognizing the local settings and constraints}

One factor contributing to the resiliency of water treaties of this sort may be the language used in forging the agreements that resolve the conflicts over water allocation. Though diplomatic language can be full of pomp and flourish that masks the realpolitik underlying relations between the contracting parties, water treaties often reflect recognition of the complexities of water dispute in a frank manner. Con- 
cessions of both material (water) and political rights (sovereignty) are evident in water treaties and described in terms that acknowledge the difficulty of balancing needs and rights. Such language can be quite explicit. For instance, the peace treaty between Jordan and Israel (1994 Article 6:3) notes, "The Parties recognise that their water resources are not sufficient to meet their needs." Despite this, what had been a source of tension and potential conflict is described as "the basis for cooperation between them as part of a practical, just and agreed solution to their water problems" (Article 2). Mutual benefit is a regular theme in the introductory language of such treaties, as is the expressed desire to maximize the utility of the resource for the affected peoples (Bangladesh-India 1977).

Despite the often-tense relations between riparian states, the treaties speak of an effort to promote neighborly relations in and around the execution of the water agreements. The language of cooperation, sharing, participation, benefit, and consideration marks the treaties. Indeed, it is often the stated obligation of one of the parties to protect their contractual partner from harm and insure their "legitimate" interests (Austria, Germany, Switzerland 1966; Convention on the Non-Navigational Uses of International Watercourses, 1997 Article 7). The language used in water treaties shows that negotiators see a need for long-term relationships between riparians and often reflects the unique circumstances of the particular relationship. In short, riparian negotiations often produce good agreements, and these agreements are expressed in diverse manners, reflecting the need for local and finely calibrated decisions.

As in the case of IRCs, the riparian simile can be introduced as a tool to assist in conflict resolution by the protagonists, or as one of the tactics deployed in the pursuit of peace by outside powers. Experience with the riparian framework suggests that any agent or combination of agents involved in a particular conflict can use it. The durability of agreements reached through a riparian framework is due, in part, to the recognition on the part of the belligerents that it is in the self-interest of all parties to abide by the agreement, thus the role of outside facilitators may be of limited scope and duration. Accordingly, we believe the experience derived from riparian conflict is useful in rethinking the issue of Jerusalem.

\section{The riparian simile: reframing Jerusalem}

Both Palestinians and Israelis relate to Jerusalem as a sacred place, and, thereby, connected to them by an eternal force. Their bond with the city is, by definition, a permanent one and one that cannot be abrogated by any secular force or other religious traditions. As we have suggested, water negotiations do not seek to end the control or use of water, but, rather, to enmesh the permanence of use in arrangements that allow for continued access by all users, albeit with modifications and accommodations. Similarly, negotiations over Jerusalem could recognize the permanent attachments of both peoples while allowing for continued access for "all users" by drawing on four interconnected touchstones. 


\section{Shift from rights to needs}

Riparian negotiations demonstrate that it is possible to move from a rights-based to a needs-based outlook. To shift from a rights to a needs orientation, policies for maintaining the city must reflect the goals of common interests, rather than parochial sovereign ends. To date, planning and policy in Jerusalem has been driven by partisan considerations and, in many respects, the political status of the city has taken precedence over the welfare of the communities. Both sides, albeit with grossly disproportionate resources, have attempted to maximize their population in Jerusalem and have contributed to crowded conditions and strain on the city's infrastructure. The face of the city reflects the partisan nature of the respective communities and their public expression, with the welfare of the opposite party receiving little consideration, as is often the case at the beginning of riparian negotiations.

The welfare of Jerusalem's residents is a particularly complex issue, and one that is often overlooked in the face of political discussions. When the welfare of individuals is considered as a need, however, it becomes an interest and obligation of the State. Negotiations over Jerusalem must be cognizant of the changes that any settlement will impose on those most directly affected by the outcome. For Palestinians in Jerusalem, there is a tension between the quality of life and services afforded by Israeli residency, and the desire to have political independence. ${ }^{3}$ It is unlikely that a Palestinian state will be able to offer anything approaching the level of welfare provided to Palestinian Jerusalemites by Israel, and there is real concern that this support would be lost with a change in political authority. Thus, any discussion that attempts to move from rights to needs should avoid absolutes that would bifurcate the city in such as way as to exacerbate economic and infrastuctural disparities in the name of political fulfillment.

There are, in fact, local models in which rights yield to needs. The Church of the Holy Sepulchre reveals a contested use of space among Christian denominations, each of which has its own territory in perpetuity. Those spaces, existing side by side, have contributed to ongoing conflict over the mundane control of sacred space (Emmett, 2000). Yet, because each denomination recognizes that there are other competing claims on sacred space, they have moved to a needs-based approach. Of course, each denomination would say they have a right to the entire space, or to more than they have been allocated. They are left controlling rooms, parts of rooms, sections of wall or floor, or with restricted prayer times, particular ceremonial functions (such as washing portions of the structure in anticipation of the Easter holiday), and so on. Indeed, the Holy Sepulcher is so contested that keys to the structure have, for hundreds of years, been entrusted to a Jerusalem Muslim family as a guard against

\footnotetext{
${ }^{3}$ When Israel conquered the Arab parts of Jerusalem in 1967 it extended an offer of citizenship to the Palestinian residents of the city. Those who declined the offer, nearly the entire Palestinian population, were nonetheless granted a package of entitlements including national health care, employment insurance, and so on. Their political rights were limited to participation in municipal elections and, unless they now request Israeli citizenship, they are barred from voting in Israeli national elections. Since Oslo, however, they do vote in Palestinian "national" elections without forfeiting their benefits from Israel.
} 
undue influence for any single Christian community. Despite the enduring tension, the denominations have codified agreements, imposed by Ottoman rulers, that were designed to allow them to have their minimal needs met.

\section{Focus on time rather than on sovereignty}

As the riparian negotiations demonstrate, time can be manipulated as a variable to ensure that all concerned parties have access to the water resource. Similarly, in the Jerusalem negotiations, time might be placed in the foreground allowing Israelis and Palestinians to place their arguments about sovereignty in the background. The model of sequential use is one option drawn from riparian negotiations: the same space can serve similar functions for different communities at different times. Moreover, scheduling of use can be flexible, catering to the ebb and flow of religious calendars. Both sides can have their needs met in the absence of exclusive control and the place/resource maintains its integrity.

The Tomb of the Patriarchs in the city of Hebron provides an intriguing illustration of the use of time to better allow for sharing of a religious site, despite significant outbreaks of violence in 1929 and 1994. The site offers an over-lapping use as a synagogue and a mosque, and both Jews and Muslims are able to pray there. Israelis and Palestinians have agreed that for 10 days each year Jews will have control of the entire site during Jewish holidays. In turn, Muslims control the entire site for 10 days each year to honor important days on their calendar (Klein HaLevi, 1997). In addition, non-Muslim worshippers are not allowed on site on Fridays. Violence there has necessitated intense guarding and separate entrances, and the situation is certainly conflictual and problematic, but both sides can have their basic needs met in the absence of exclusive control, and the place/resource maintains its integrity.

Perhaps space, like water, can be used in ways that ensure permanent part-time access. As a variable of plasticity, time might be used as method to restructure the frame of sovereignty. Like water, space can be used in ways that acknowledge permanent attachment but provide for part-time access. Jerusalem might then be the eternal yet shared capital of two peoples.

\section{Calibration to beneficial use}

IRC negotiations generally include language that calls for both sides to respect the integrity of the water, making efforts to protect its quality, or even improve it, so that the partners in the agreement can use it in an appropriate manner. Because riparian treaties are tailored to account for the unique circumstances of the water conflict, they tend to maximize the possibility that the major needs of the negotiators are met.

In more practical terms, the peace dividend will have economic implications for Jerusalem and its residents, and translate into benefits for individuals and communities. Much of that economic benefit would stem from the ability to develop tourism, both internal and international, which would capitalize on precisely those places that 
are the sticking point in the negotiations. In this way, a point of contention would be converted into a source of benefit for both sides.

The case of the mosque/synagogue in Hebron again serves as a model for a broader approach to Jerusalem. A leaking roof at that facility would jeopardize a resource enjoyed by both parties, and, clearly, there are common interests for Palestinians and Israelis in Jerusalem. Protracted conflict is clearly detrimental to the residents of Jerusalem, while a "peace dividend" will be in some ways intangible, yet of obvious benefit to them. The absence of violence and the tension that accompanies it, the cessation of security measures, and the broader access to the city for all of its residents would represent a significant gain in the quality of life.

\section{Language recognizing the local settings and constraints}

Today Jerusalem is carved into discrete spaces, both formally and informally, in which the two sides operate separately (Romann \& Weingrod, 1991; Sharkansky and Auerbach, 2000:405). Though there is some overlap, interactions are generally by necessity rather than desire and contact points between Israelis and Palestinians are a source of tension. The negotiations over Jerusalem have faltered over the issue of the Temple Mount, a particularly significant site for Israelis and Palestinians, despite the de facto separation that has ascribed use of the Western Wall for Jewish worship and the Al Aqsa mosque and Dome of the Rock for Muslim worship. The problem, for both sides, is the official control over the Temple Mount, with that space seen as a vital component of national and religious dignity. For both communities, as they currently argue it, national identity will be hollow without being able to claim sovereignty over their particular holy sites (which includes control of the holy places of the other side as well).

To this end, language that makes agreement possible must reflect the inherent frustration that both sides will experience in sharing a unified Jerusalem. Historic claims and arguments will not be fully resolved by a present-day accommodation for ruling the city, despite the lofty language of treaty making. The Declaration of Principles between the two parties states that each side will recognize the other's "mutual legitimate and political rights, and strive to live in peaceful coexistence and mutual dignity and security and achieve a just, lasting and comprehensive peace settlement and historic reconciliation through the agreed political process." It is crucial that thinking about Jerusalem shift from mutual recognition of rights to mutual recognition of needs. The question of rights will linger, while the question of needs can, at least in part, be productively addressed. As in the IRCs, it is clear that the alternative to such progress is ongoing conflict and quite possibly an escalation of the violence that has marked the region of late. The costs of such a situation suggest that a price, even a steep one, should be paid for a negotiated resolution.

Riparian negotiations suggest that language that recognizes needs, time as a flexible variable, and a focus on maximizing the benefits of the resource may encourage local problem solving. Such language will have to account for not only the vested interests of the immediate residents, but for the competing nationalist agendas, and the sensitivities of broader international religious communities. Thus, in speaking of 
the benefits that come from a riparian-style agreement, negotiators will have to address concerns that are not typically found in a river basin dispute. Yet here, too, moving from a rights-based to a needs-based orientation will prove useful, in that issues of access and claims of legitimacy and authenticity can only be assuaged through resolutions that give satisfaction to more than one party.

\section{Jerusalem and the riparian simile}

To show how the riparian simile might be deployed in relation to Jerusalem, we offer the following brief example, with the caveat that it is intended as an illustration of the potential of this approach, rather than as a refined blueprint with concrete proposals. We address a core of the sovereignty obstacle, the Temple Mount, where neither side has been able to compromise on its demand for control of the holy places. Israel refuses to cede sovereignty over the surface of the Temple Mount itself. This is the site of the Jewish Temples destroyed long ago, but now dominated by sacred Islamic structures. Palestinians continue to demand sovereignty over areas of the compound, both exposed and subsurface. Rather than plotting all of the nuances of this tangled geography of dispute, we note simply that in regard to the most sacred of places, both sides remain entrenched in maximalist, zero-sum assertions of sovereignty, and these assertions continue to scuttle progress in the peace talks. Our question, then, is in what manner can the riparian simile be useful in breaking this impasse?

In-as-much as both sides cleave to their claim that sovereignty is both a right and a need (in both emotional and religious terms) it seems nearly impossible to place a wedge that would facilitate compromise. Thinking in riparian terms, however, generates a number of possibilities. To begin with, we believe that the tension can be somewhat lessened by diluting the conflict by broadening the area. The Temple Mount is measured in hectares and the Western Wall in meters, yet each is treated as part of an indivisible whole. If that whole were expanded to something slightly larger, to the square kilometer area of the Old City of Jerusalem, for instance, more options might be available. We find a riparian analogue for this scalar shift in that a river is viewed as an organic whole while, simultaneously, allowing the various parties to relate to their portion of the river as their "own." If the two sides could agree to share sovereignty over the broader area containing the sacred places, there could be a shift to the needs that both sides have in accessing and maintaining them. Negotiations for sovereignty over the holy places would give way to the technical problems of access and upkeep, analogous to that of the Holy Sepulchre or the Tomb of the Patriarchs in Hebron, or to water sharing arrangements, thereby rewarding cooperative measures.

Among these measures could be time-sharing measures that allow specific functions of religious and communal observation to take precedence, with the respective Sabbaths of Friday (Muslim), Saturday (Jewish), and Sunday (Christian) and holy day schedules dictating patterns of traffic, commerce, and municipal affairs to the benefit of the various communities. In broader terms, sharing administration of the 
Old City would facilitate joint planning and regulation of the complex infrastructure needed to support the mix of residence, commerce, and religious/tourist activity taking place in a confined space burdened by preservation needs and the challenges of antiquation.

De facto arrangements currently maintained by the Israeli government recognize the sacred nature of Muslim and Christian spaces in Jerusalem and the language of joint custodianship over the Old City can enshrine that recognition and make it fully reciprocal. With a sharing arrangement for the Old City, both Palestinians and Israelis will be able to claim the control that is a central element of their respective national identities and create territorial contiguity with their communities residing outside the Old City walls.

In this way, the negotiations would attempt to identify what is needed for each side to be able to address its sovereign rights in relation to the holy places in the Old City, a matter of practicalities rather than zero-sum convictions. The shift from rights to needs entails a discussion of sharing that accounts for the ebb and flow of religious and political currents in both space and time. A result of this type of coordination would be an improvement in the quality of life and infrastructure of the Old City and the dedication of resources to constructive measures rather than the ongoing drain of violence and confrontation. Such a model, evolving out of the complexities of the conflict and embracing such sensitive locations, could reflect in word and deed the elevation of the welfare of local residents and their allied communities above the partisan dispute that continues to mark the zero-sum approach to controlling the sacred sites. From that starting place, the model could readily be adapted to more of Jerusalem and, perhaps, beyond.

\section{Limitations and implications}

While we see the benefits of considering the riparian analogue, we also recognize the limitations of our argument. First, conceptual exercises can be criticized for having little bearing on policy making. Such criticisms are justified if policy making is conducted without the aide of concepts that have been tested with the details of place, as have the riparian treaties analyzed in the TFDD. Our attempt to provide an innovative way of thinking about territorial disputes draws upon considerable experience in riparian negotiations that has been subjected to rigorous analysis. Newman and Paasi illustrate the benefits of conceptual exercise as they have invited geographers to reconsider boundary analysis, sociospatial identities, and socialization narratives in light of recent transformations in Europe. Their work is designed to offer a multidisciplinary framework for the analysis of boundaries and identity, from which policies might be derived. Similarly, we offer our contribution as an attempt to rethink the framework used to structure the Jerusalem issue, rather than as a plan to be implemented according to particular dictates. As a conceptual exercise, we invite scholars and others to derive principles from riparian negotiations that might be useful in territorial negotiations. We believe the riparian analogue suggests a multi-dimensional framework broader than the one used by those who are negotiating the respective sovereign claims to the city. 
A second limitation of our approach is our apparent neglect of the power issue. Clearly, there is an asymmetric power relationship between Israelis and Palestinians, as Israelis command an overwhelming military force and a first-world economic base compared to the developing economy of the Palestinians. Indeed, there is evidence to suggest that on water issues, Israelis have made use of this power imbalance to the detriment of the Palestinians (Isaac, 2000). The riparian analogue suggests, however, that even in the face of asymmetric power relations, negotiators are able to reframe the issues on the basis of respective needs. We believe that it opens up new angles of approaching the issue of Jerusalem, approaches that acknowledge the power issue, but recast it so that needs are at the forefront.

A third limitation is also apparent, as we do not offer a specific policy designed to address the competing claims to Jerusalem. Many innovative solutions have been offered for the Jerusalem conflict. A number of them, such as Clinton's bridging proposal, have been made in the spirit of preserving sovereignty; others have proposed a range of mechanisms for governing Jerusalem. Such mechanisms have included condominium arrangements, expansion of the city boundaries, territorial enclaves and exclaves, cantons or boroughs, and so on (see the 63 proposals on Jerusalem in Hirsch, Housen-Couriel, \& Lapidloth, 1995). We see potential among these and other solutions. Indeed, as we suggested at the outset, we hope that our approach can create the space necessary to allow such solutions to take root. In-asmuch as the negotiations have foundered on the issue of sovereignty, we believe that the riparian analogue offers a framework that could invite serious consideration of the host of solutions that are available.

We see our study making three contributions to the literature. Initially, we offer scholars of political geography insight into analogical thinking and the simile. While geographers have long employed the metaphor, they have not made use of the simile. Like the metaphor, the simile offers the possibility of conveying the social meaning of space through analogical thinking. While metaphor aggregates space, the simile disaggregates space. As such, the simile invites the use of relaxed analogies for the purposes of discovering relevant similarities between two spheres. Creative use of the simile can prompt frame restructuring of a conflict, helping belligerents to identify alternatives that may be blocked by the reigning metaphors. The riparian simile illustrates the benefits of restructuring the Jerusalem conflict and we are hopeful political geographers will see the utility of the simile in their studies of space.

Second, we detail the characteristics of successful riparian negotiations, revealing how they produce needs-based solutions to water conflict. We have suggested that the four principles developed out of the experience of riparian negotiations, a shift from rights to needs, a focus on time rather than on sovereignty, calibration to beneficial use, and language recognizing the local settings and constraints, might be applied to other conflicts, such as the one over Jerusalem. In making this application, the principles of riparian negotiations offer a framework for negotiating national and religious disputes over territory.

Finally, our interdisciplinary collaboration confirms the themes developed by the authors of the special issue of Political Geography (vol. 18, issue 8). In the course of our study, we affirm the value of geography in illuminating issues of space and 
place. In turn, the field of political communication offers the resources needed to understand and explain the use of language in shaping perceptions of place. In attempting to align disciplines in search of plausible alternatives to the current impasse over Jerusalem, we have demonstrated the value of interdisciplinary study, as both disciplines contributed to our conclusion that the riparian simile offers an alternative to the Jerusalem impasse. We propose further research on the applicability of analogical thinking and offer the riparian alternative as a lens that may have utility in the study of territory, boundaries, place, and identity that are the bailiwick of political geographers.

\section{Acknowledgements}

The authors appreciate the helpful comments of Diane Baxter, Anthony Leiserowitz, John O'Loughlin and Aaron Wolf, along with the suggestions offered by the anonymous reviewers.

\section{References}

Alpher, J. (2000). Intifada backgrounder: facts and analysis. Americans for Peace Now. Available Online: http://www.peacenow.org/nia/briefs/intifadabkgnd.html (December 2000).

'Al-Ra'y', A. (2000). “Jordanian sources “flatly deny” Israel reduced Jordan's water quota.” BBC Monitoring Middle East. Available Online: Nexis, Mead Corporation (December 2000).

Amichai, Y. (2000). C. Bloch, C. \& C. Kronfeld. translators Jerusalem, Jerusalem, Why Jerusalem? Open, Closed, Open. New York: Harcourt Inc.

Benvenisti, M. (1996). City of stone: the hidden history of Jerusalem. Berkeley: University of California Press.

Benvenisti, M. (Dec. 28, 2000). Bridging the gaps in Jerusalem. Haaretz. (Online version).

Bingham, G., Wolf, A., \& Wohlgenant, T. (1994). Resolving water disputes: conflict and cooperation in the U.S., Asia, and the Near East. Washington, DC: US Agency for International Development.

Boulding, E. (1994). Building peace in the Middle East: challenges for states and civil society. Boulder, Colo: Lynne Rienner.

Brewer, S. (1996). Exemplary reasoning: semantics, pragmatics, and the rational force of legal argument by analogy. Harvard Law Review 109. Available Online: Academic Universe: Mead Corporation (2001).

Bridgeman, T. (1996). On the likeness of similes and metaphors. Modern Language Review, 91, 65-78.

Buttimer, A. (1982). Musing on Helicon: root metaphors and geography. Geografiska Annaler, 64B, 89-96.

Butts, K. (1997). The strategic importance of water. Parameters, 2, 65-83.

Elazar, D. J. (1999). Political science, geography, and the spatial dimension of politics. Political Geography, 18(8), 875-886.

Elmusa, S. (1997). Water conflict: economics, politics, law and Palestinian-Israeli water resources. Washington, DC: Institute for Palestine Studies.

Emmett, C. F. (2000). Sharing sacred space in the Holy Land. In A. B. Murphy, \& D. L. Johnson (Eds.), Cultural encounters with the environment: Enduring and evolving geographic themes (pp. 261-282). Lanham, MD: Roman and Littlefield.

Feitelson, E. (2001). Implications of shifts in Israeli water discourse for Israeli-Palestinian water negotiations. Political Geography (in press). 
Gleick, P. (1993). Water and conflict: fresh water resources and international security. International Security, 18(1), 79-112.

Gleick, P. (1998). The world's water 1998-1999: the biennial report on freshwater resources. Washington: Island Press.

Gorbachev, M. (Dec. 9, 2000). A new Middle East peace initiative. International Herald Tribune, p. 8.

Hirsch, M., Housen-Couriel, D., \& Lapidoth, R. E. (1995). Whither Jerusalem?: proposals and positions concerning the future of Jerusalem. The Hague: Martinus Nijhoff.

Hillel, D. (1994). Rivers of Eden: the struggle for water and the quest for peace in the Middle East. New York: Oxford University Press.

Holyoak, K. J., \& Thagard, P. (1995). Mental leaps: analogy in creative thought. Cambridge, Mass: MIT Press.

Homer-Dixon, T. (1994). Environmental scarcities and violent conflict: evidence from cases. International Security, 19(1), 5-40.

Homer-Dixon, T. (1999). Environment, scarcity, and violence. Princeton: Princeton University Press.

Isaac, J. (2000). The essentials of sustainable water resource management in Israel and Palestine. Arab Studies Quarterly, 22, 13-32.

Khalidi, R. (1997). Palestinian identity: the construction of modern national consciousness. New York: Columbia University Press.

Klein HaLevi, Y. (May 15, 1997). The next minefield. Jerusalem Report Available Online: Nexis-Lexis: Mead Corporation.

Kolars, J. (1997). River advocacy and return flow management on the Euphrates/Firat river. Water International, 22, 49-53.

Lapid, Y. (1999). Where should we begin? Political geography and international relations. Political Geography, 18(8), 895-900.

Livingston, D. N., \& Harrison, R. T. (1981). Meaning through metaphor: analogy as epistemology. Annals of the Association of American Geographers, 81, 95-107.

Lustick, I. (1999). Geography and political science. Political Geography, 18(8), 901-904.

Murphy, A. (1990). Historical justifications for territorial claims. Annals of the Association of American Geographers, 80, 531-548.

Murphy, A. (1999). "Living together separately". Thoughts on the relationship between political science and political geography. Political Geography, 18(8), 887-894.

Newman, D. (1999). Comments on Daniel Elazar, political geography and political science. Political Geography, 18(8), 905-912.

Newman, D., \& Paasi, A. (1998). Fences and neighbors in the postmodern world: boundary narratives in political geography. Progress in Human Geography, 22(2), 186-207.

Palestine, Voice of. (Jan. 9, 2001). "Jerusalem mufti issues fatwa on mosques in Islam." British Broadcasting Corporation. Available Online: Nexis-Lexis: Mead Corporation, 2001.

Perelman, C., \& Olbrechts-Tyteca, L. (1969). The new rhetoric: a treatise on argumentation. Notre Dame, [Ind.]: University of Notre Dame Press.

Porteous, J. D. (1986). Bodyscape: the body-landscape metaphor. The Canadian Geographer, 30, 1.

Porteous, J. D. (1990). Landscapes of the Mind: Worlds of Sense and Metaphor. Toronto: University of Toronto Press.

Reeves, P. (Jan. 6, 2001). Protests and a PR battle for 'Judaism's holiest site.' The Independent, p. 16. Available Online: Nexis-Lexis: Mead Corporation, 2001.

Robinson, J. (1998). Spaces of democracy: remapping the apartheid city. Environment and Planning: Society and Space, 16, 533-548.

Romann, M., \& Weingrod, A. (1991). Living together separately: Arabs and Jews in Contempary Jerusalem. Princeton, NJ: Princeton University Press.

Schama, S. (1996). Landscape and memory. New York: Knops.

Sharkansky, I., \& Auerbach, G. (2000). Which Jerusalem? A consideration of concepts and borders. Environment and Planning D: Society and Space, 18, 395-409.

Sharm el-Sheikh Fact-Finding Committee. Report (2001). Available Online: http://usinfo.state.gov/ regional/nea/mitchell.htm., 2001.

Siegel-Itzkovich, J. (January 6, 2001). Dead Sea shrinkage causing soil collapse. Jerusalem Post, p. 16. 
Smith, N., \& Katz, C. (1993). Place and the politics of identity. In M. Keith, \& S. Pile (Eds.), Grounding metaphor: towards a spatialized politics (pp. 76-83). New York: Routledge.

Soffer, A. (1999). Rivers of fire: the conflict over water in the Middle East. Lanham: Rowman \& Littlefield Publishers, Inc.

Sontag, D. (January 5, 2001). Dare from Palestinians. New York Times, p. 1.

Starr, J. (1991). Water wars. Foreign Policy, 82, 17-36.

Sunstein, C. R. (1993). On Analogical Reasoning. Harvard Law Review 106 (1993) Available Online: Lexis, Mead Corporation. 2001.

Thompson-Klein, J. (1996). Crossing boundaries: knowledge, disciplinarities, and interdisciplinarities. Knowledge, disciplinarity and beyond. Charlottesville, Va: University Press of Virginia.

Wapner, P. K., Ruiz, L. E. J., \& Falk, R. A. (2000). Principled world politics: the challenge of normative international relations. Lanham, Md: Rowman \& Littlefield.

Wescoat, J. L. (1992). Beyond the river basin: The changing geography of international water problems and international watercourse law. Colorado Journal of International Environmental Law and Policy, 3, 301-330.

Wescoat, J. L. (1995). Main currents in early multilateral water treaties: A historical-geographic perspective 1648-1948. Colorado Journal of International Environmental Law and Policy, 7(1), 39-74.

Willems-Braun, B. (1997). Buried epistemologies: the politics of nature in (post)colonial British Columbia. Annals of the Association of American Geographers, 70, 3-31.

Wolf, A. T. (1999a). Criteria for equitable allocations: the heart of international water conflict. Natural Resources Forum, 23, 3-30.

Wolf, A. (1999b). "Water wars" and water reality: conflict and cooperation along international waterways In S. C. Lonergan (Ed.), Environmental change, adaptation and human security. Dordrecht: Kluwer.

Wolf, A.T. (2000). Transboundary Freshwater Dispute Database. Available Online: http://terra.geo. orst.edu/users/tfdd/, 2001. 